\begin{tabular}{|c|c|}
\hline \multirow{3}{*}{ 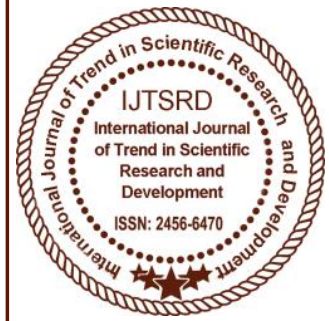 } & $\begin{array}{l}\text { International Journal of Trend in Scientific } \\
\text { Research and Development (IJTSRD) }\end{array}$ \\
\hline & International Open Access Journal \\
\hline & ISSN No: 2456 - 6470 | www.ijtsrd.com | Volume - 2 | Issue -4 \\
\hline
\end{tabular}

\title{
Application of Industrial Engineering to increase the productivity of an E-Rickshaw factory
}

\author{
${ }^{1}$ Harshna Gupta, ${ }^{2}$ Gaurav Chaudhary, ${ }^{3}$ Krishna Mohan Singh, ${ }^{4}$ Devendra Kumar, ${ }^{5}$ Ashish Malik \\ $1,2,3,4$ B. Tech Students, ${ }^{5}$ Faculty \\ 1,2,3,4,5 Department of Mechanical Engineering, \\ 1,2,3,4,5 $\mathrm{ABES}$ Engineering College, Ghaziabad, Uttar Pradesh, India
}

Abstract-- Productivity improvement is an important issue in small-scale industry. The profit earning of this industry largely depends on productivity improvement. This study shows the way of finding gap of production process and operations. By implementing work study and method study and established new effective process for particular operation, we have to able to increase productivity. Especially this study shows the improvement of productivity in assembly area of E-rickshaw manufacturing industry. The line balancing is the key point to increase productivity to particular products. After line balancing and critical analysis the work content was reduced by 9 minutes. Our proposed method helps to increase productivity to $19.97 \%$ with reduction of work content and line balancing.

Keywords-- Productivity, Time Study, Motion Study, Work Content

\section{INTRODUCTION}

Nowadays, the rise in wages in the developed countries has impacted on the direction of the manufacturing industry development in the developing countries, like India. In the developing countries, particularly India, the cheaper wages have attracted many foreign investors to open their factories in India. However, the affordable wages paid by the company turn out to be unsupported by the company productivity. Studies suggest that in terms of workforce productivity the factories in India are still lag far behind the developed countries.

Moreover, a large number of challenges exist in a labour-intensive company that involve many processing activities as well as manual assembly activities, because of this productivity issues are obviously more likely to be encountered. It often causes the query that emerges from the stakeholder, about how to increase the productivity and create a flexible production system to overcome the business trend that rapidly changes.

We found that for changing the productivity of a company, time is an essential tool. First of all it is crucial to determine the standard time required to perform the task, or the average time required by an average skilled worker to perform the task under normal conditions. Once this time is determined only then we can devise ways to reduce it, standardise it and apply it in the industry. The following report has identified those key stages where time consumption is to be optimised. Then the stages are further divided into smaller elements. The time taken to perform these elements is calculated and by carrying out certain calculations the standard time is found out.

\section{RESEARCH METHODOLOGY}




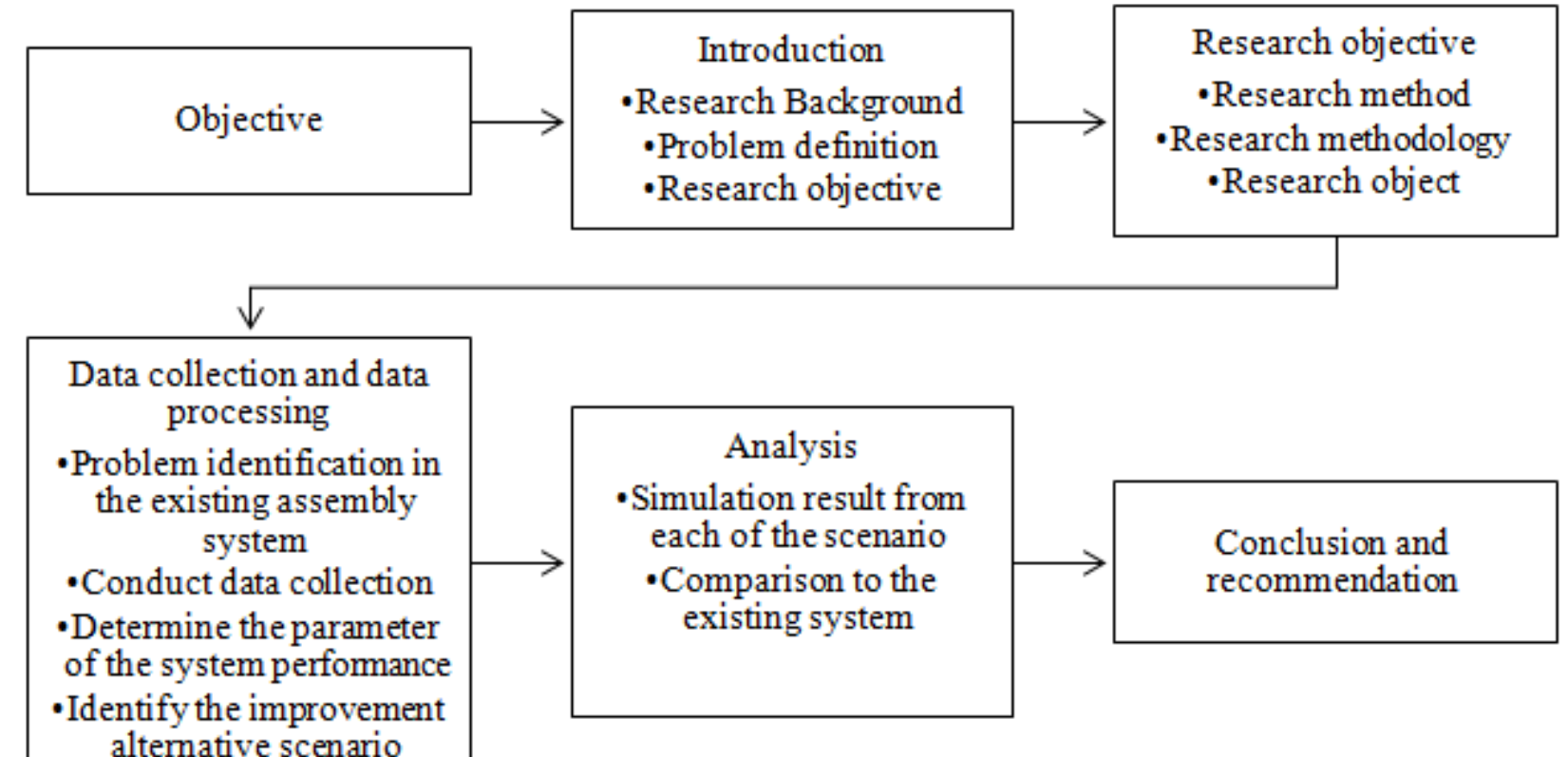

\section{RESEARCH OBJECT}

\section{A. Company Overview}

The Company was formed in 2005 under the Company's Director Mr. Sahab Singh, who is having a vast experience of more than 15 years in the field of automobile and finance. The company started its operations through JSA 3 wheelers \& soon become the first to sell out the best product in India and then there was no looking back4 as the company spread its wing across business verticals, including Atul Auto Ltd, Continental Engines Ltd \& JSA 3 Wheelers. The Group quest to make it big in the market, made it fray into another business of manufacturing \& exporting E- rickshaw under the company, Om Balajee Automobile (I) Pvt. Ltd which shows the vision of the group to make productive use of modern day technology, keeping the innovation factors intact. Their E- Rickshaws are available with model name " DMW" ( Deshwar Motor Works) which are meant to carry passengers and loads. All these E rickshaws run on chargeable battery and require no manual effort, which outflow the use of costly fuels. Thus, 800 components of their E- Rickshaw are manufactured by the company. Their E- Rickshaws are apparently the best that can appear out of the technological innovation experiments.

\section{B. Assembly department overview}

We found that amongst all the departments in the factory, the one that requires the most attention was the assembly area. There are various priorities on the basis of which task or job to be studied is selected such as bottleneck or repetitive jobs, jobs with longer cycle time, to check correctness of existing time, comparison of two methods etc. This was selected on basis of our observation and company's recommendation.

\section{Chassis assembly process}

\section{a. Stage 1}


International Journal of Trend in Scientific Research and Development (IJTSRD) ISSN: 2456-6470

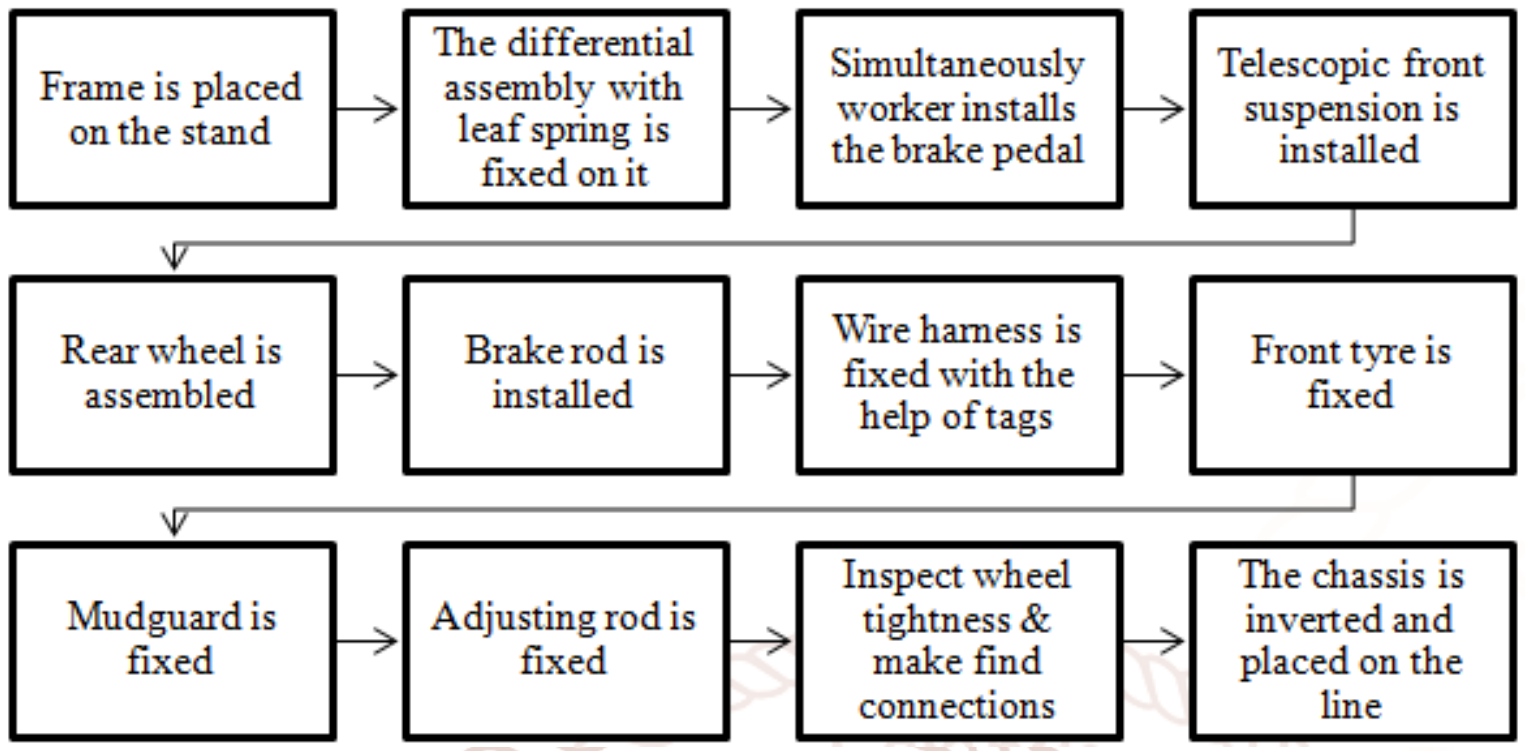

\section{b. Stage 2}

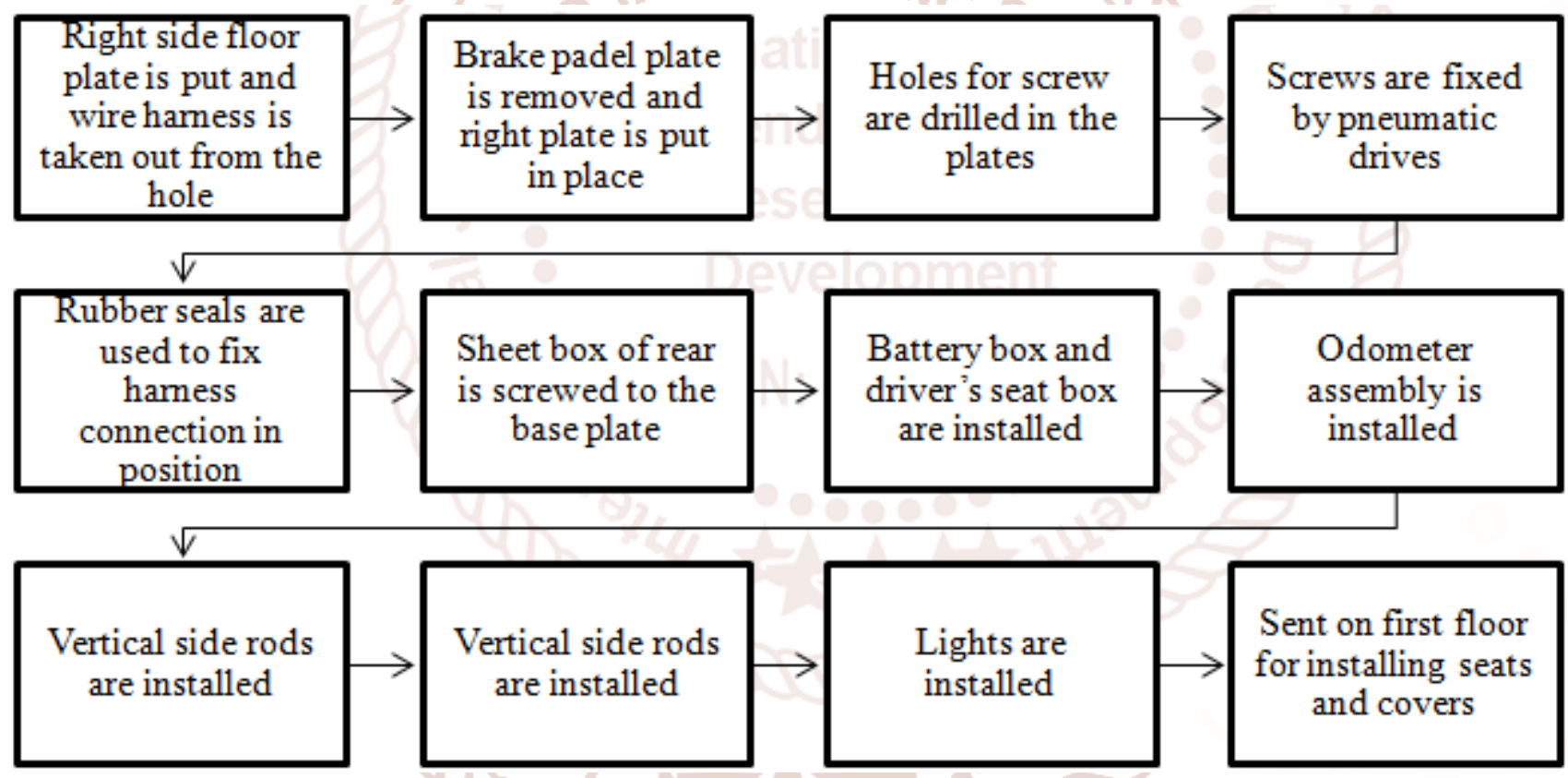

\section{DATA COLLECTION AND TABULATION}

\section{A. Selection of task to be timed:}

We found that amongst all the departments in the factory, the one that requires the most attention was the assembly area. There are various priorities on the basis of which task or job to be studied is selected such as bottleneck or repetitive jobs, jobs with longer cycle time, to check correctness of existing time, comparison of two methods etc. This was selected on basis of our observation and company's recommendation.

\section{B. Standardizing the method of working:}

The flowcharts were not available so we developed the process flow charts on the two stages. (Explained later)

\section{Selection of operator for study:}

Since this involves heavy parts, Workers do not carry out operations individually but in pairs or groups. So we recognized that operations were performed by 5 groups however they all not hard \& fast.

\section{Recording the details:}

General information about activities and the problem areas noted down. Name of labour, task/job performed, department, section of work activity, general information 


\section{E. Breaking the task into elements:}

The two stages where further divided into smaller elements stage 1 in 11 and stage 2 in 12 smaller elements.

\section{F. Determining no of cycles to be measured:}

From the guide, it was noted that the each stage takes from 20 to 40 mins so clearly, 5 cycles are recommended.

Number of recommended cycles for time study

\begin{tabular}{|l|c|c|c|c|c|c|c|c|c|c|c|}
\hline $\begin{array}{l}\text { Minutes Per } \\
\text { Cycle }\end{array}$ & $\begin{array}{c}\text { To } \\
0.10\end{array}$ & $\begin{array}{c}\text { To } \\
0.25\end{array}$ & $\begin{array}{c}\text { To } \\
0.50\end{array}$ & $\begin{array}{c}\text { To } \\
0.75\end{array}$ & $\begin{array}{c}\text { To } \\
1.0\end{array}$ & $\begin{array}{c}\text { To } \\
2.0\end{array}$ & $\begin{array}{c}\text { To } \\
5.0\end{array}$ & $\begin{array}{c}\text { To } \\
10.0\end{array}$ & $\begin{array}{c}\text { To } \\
20.0\end{array}$ & $\begin{array}{c}\text { To } \\
40.0\end{array}$ & $\begin{array}{c}\text { Over } \\
40\end{array}$ \\
\hline $\begin{array}{l}\text { Number of } \\
\begin{array}{l}\text { Cycles } \\
\text { Recommended }\end{array}\end{array}$ & 200 & 100 & 60 & 40 & 30 & 20 & 15 & 10 & 8 & 5 & 3 \\
\hline
\end{tabular}

Source: A.E.Shaw:"stopwatch time study", in H.B.Maynard (ed): Industrial Engineering Handbook, op.cit.Reproduced by kindpermission of the McGraw Hill Book Company.

\section{G. Measuring each element using stop watch:}

Time taken in each element is calculated by fly black method. This time is called the observed time.

\section{H. Methods of timing using Stopwatch:}

There are two methods of timing using a stop watch. They are: Fly back or Snap back method and Continuous or Cumulative method.

\section{a. Fly back Method:}

Here the stop watch is started at the beginning of the first element. At the end of the element the reading is noted in the study sheet. At the same time, the stopwatch hand is snapped back to zero. This is done by pressing down the knob, immediately the knob is released. The hand starts moving from zero for timing the next element. Thus the timing for each element found is called observed time.

\section{b. Continuous method:}

Here the stop watch is started at the beginning of the first element. The watch runs continuously throughout the study. At the end of each element the watch readings are recorded on the study sheet. The time for each element is calculated by successive subtraction. The final reading of the stop watch gives the total time known as observed time.

\section{Determine standard rating:}

This performance seldom conforms to the exact definition of normal or standard. Therefore, it becomes necessary to apply some 'adjustment' to the mean observed time to arrive at the time that the normal operator would have taken to do that job when working at an average pace. This 'adjustment' is called Performance Rating.

Performance Rating can be defined as the procedure in which the time study engineer compares the performance of operator(s) under observation to the Normal Performance and determines a factor called Rating Factor.

$$
\text { Rating Factor }=\frac{\text { Observed Performance }}{\text { NormalPerformance }}
$$

\section{J. System of Rating}

There are several systems of rating the performance of operator on a job.

- Pace Rating

- Westinghouse System of Rating

- Objective Rating

- Synthetic Rating

\section{a. Pace Rating}

Under this system, operator's performance is evaluated by considering his rate of accomplishment of the work. The study person measures the effectiveness of the operator against the concept of normal performance and then assigns a percentage to indicate the ratio of the observed performance to normal or standard performance. In this method, which is also called the speed rating method, the time study person judges the operators speed of movements, i.e. the rate at which he is applying himself, or in other words "how fast" the operator performs the motions involved.

The average observed times of the elements of the two stages: 
Stage 1

\begin{tabular}{|l|l|l|l|l|l|l|l|l|l|l|l|l|}
\hline $\begin{array}{l}\text { Element } \\
\text { No. }\end{array}$ & 1 & 2 & 3 & 4 & 5 & 6 & 7 & 8 & 9 & 10 & 11 & 12 \\
\hline $\begin{array}{l}\text { Element } \\
\text { Type }\end{array}$ & $\mathrm{M}$ & $\mathrm{M}$ & $\mathrm{M}$ & $\mathrm{M}$ & $\mathrm{M}$ & $\mathrm{M}$ & $\mathrm{M}$ & $\mathrm{M}$ & $\mathrm{M}$ & $\mathrm{M}$ & $\mathrm{M}$ & $\mathrm{M}$ \\
\hline $\begin{array}{l}\text { Average } \\
\text { actual time } \\
\text { in minutes }\end{array}$ & 2 & 5 & 3 & 3 & 4 & 7 & 5 & 2 & 1 & 3 & 1 & 1 \\
\hline
\end{tabular}

\section{Stage 1 actual observed times}

Stage 2

\begin{tabular}{|l|l|l|l|l|l|l|l|l|l|l|l|}
\hline $\begin{array}{l}\text { Element } \\
\text { No. }\end{array}$ & 1 & 2 & 3 & 4 & 5 & 6 & 7 & 8 & 9 & 10 & 11 \\
\hline $\begin{array}{l}\text { Element } \\
\text { Type }\end{array}$ & $\mathrm{M}$ & $\mathrm{M}$ & $\mathrm{P}$ & $\mathrm{P}$ & $\mathrm{M}$ & $\mathrm{M}$ & $\mathrm{M}$ & $\mathrm{M}$ & $\mathrm{M}$ & $\mathrm{M}$ & $\mathrm{P}$ \\
\hline $\begin{array}{l}\text { Average } \\
\text { actual time } \\
\text { in minutes }\end{array}$ & 50 & 30 & 1 & 1 & 30 & 1 & 3 & 4 & 6 & 5 & 50 \\
\hline
\end{tabular}

Stage 2 actual observed times

Selection of most time-consuming elements:

\begin{tabular}{|l|l|}
\hline $\begin{array}{l}\text { Element } \\
\text { No. }\end{array}$ & 1 \\
\hline $\begin{array}{l}\text { Element } \\
\text { Type }\end{array}$ & $\mathrm{M}$ \\
\hline $\begin{array}{l}\text { Average } \\
\text { actual } \\
\text { time in } \\
\text { minutes }\end{array}$ & 2 \\
\hline
\end{tabular}
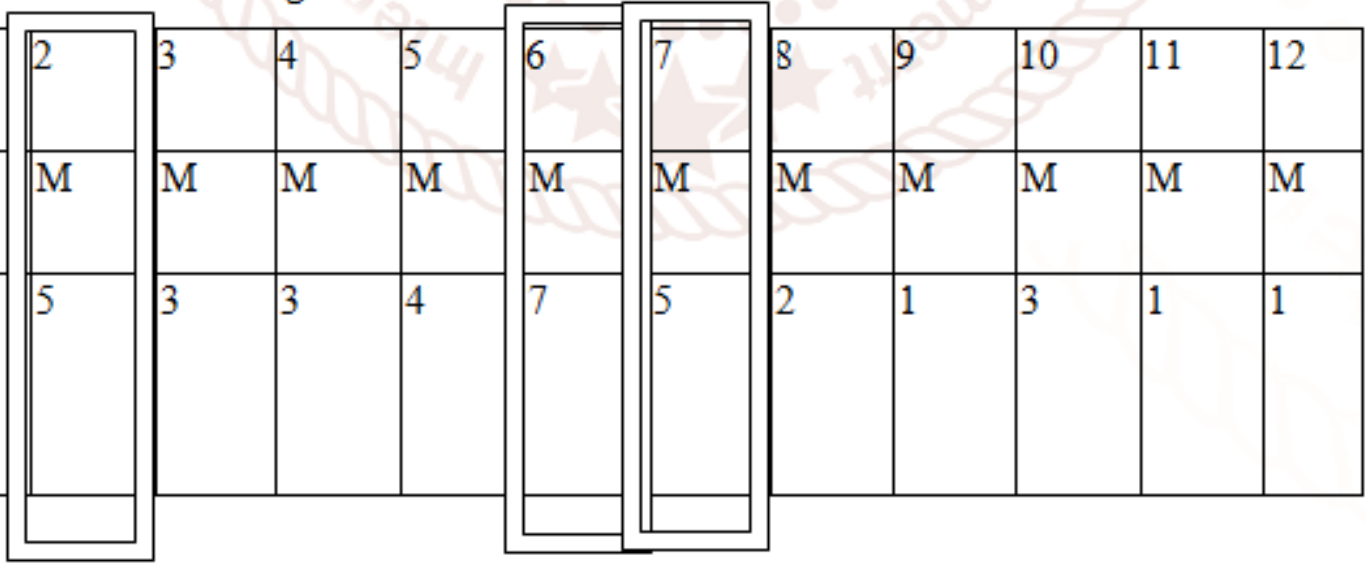

Stage 1 most time consuming elements 


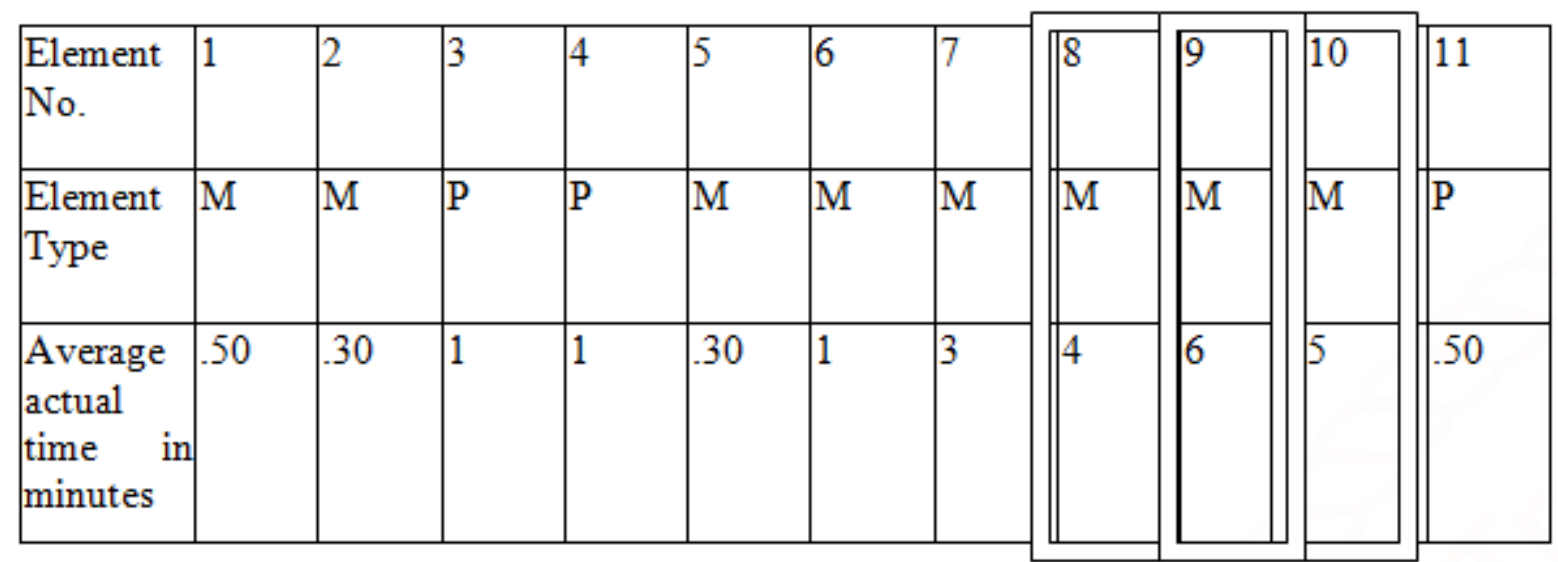

Stage 2 most time consuming elements

Now, by using some PMT system, suppose we water etc. Unavoidable delays may occur because of determine the times of these elements as

\begin{tabular}{|l|l|l|l|}
\hline Elements No. & 2 & 6 & 7 \\
\hline $\begin{array}{l}\text { Standard operators } \\
\text { time }\end{array}$ & 4.65 & 6.50 & 4.50 \\
\hline
\end{tabular}

\section{b. Standard operator's time}

Normal time for Chassis nte assembly $=0.92(2+5+3+3+4+7+5+2+1+3+1+1)$

$=38.64 \mathrm{mins}$

Normal time for stage $.90(.50+.30+.30+1+3+4+6+5)+1(1+1+.50)$

$=21 \mathrm{mins}$

It is to be noted that power controlled (or machinepaced) elements are always given 100\% rating.

\section{c. Determining the allowance:}

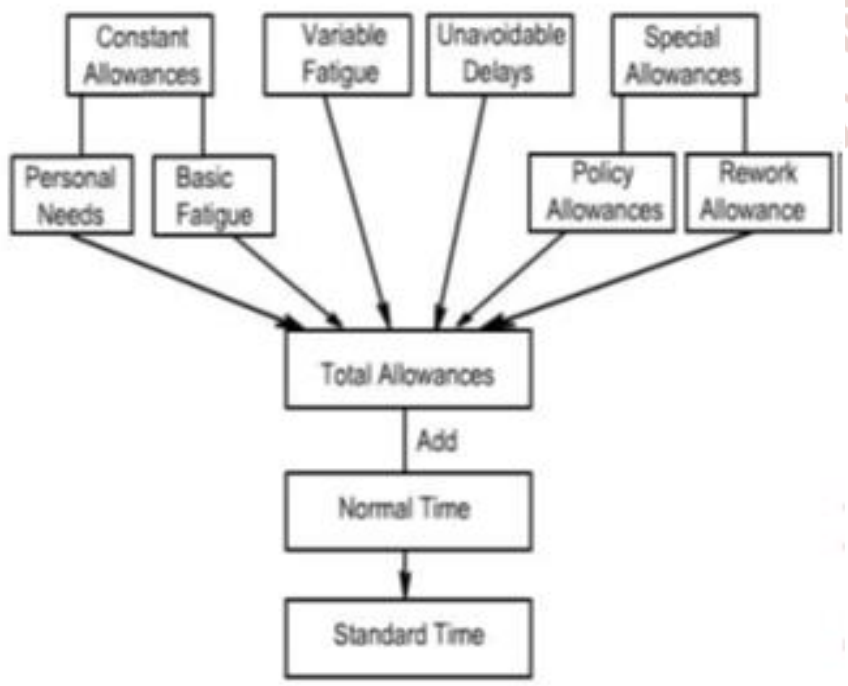

A worker cannot work all the day continuously. He will require time for rest going for toilet, drinking tool breakage etc. So some extra time is added to the normal time. The extra time is known as allowance. It is generally allotted as per the company policy. Most companies allow the following allowances to their employees.

- Constant allowances (for personal needs and basic fatigue)

- Delay Allowance (for unavoidable delays)

- Fatigue Allowance (for job dependent fatigue)

- Personal Allowance

- Special Allowance

K. Constant allowances (for personal needs and basic fatigue) calculations:

Fatigue Allowance (for job dependent fatigue 4\% of normal time $)=.04 \times 38.64=1.5$

Personal Allowance (5\% nearly 24 minutes in 8 hours $)=.05 \times 38.64=1.932$

Special Allowance $(7 \%)=2.708$

Determine the standard time:

The standard time is the sum of Normal time and allowances. Thus, it is calculated as below:

Standard Time $=$ Normal Time + Allowances

$=38.64+1.5+1.93+2.7=44.77 \mathrm{mins}$

\section{PROPOSED CHANGES IN PROCESS}

After studying all of those operations, we found some problem which is improved during proposed method implication to our research work. We have done some critical operations for productivity improvement to these specific products. Following table shows the critical operations which is done during implementation our research framework. 


\begin{tabular}{|l|l|l|}
\hline $\begin{array}{l}\text { Name of the } \\
\text { Operation }\end{array}$ & Existing method & Suggested method \\
\hline $\begin{array}{l}\text { Bringing Chassis } \\
\text { frame to assembly } \\
\text { stand }\end{array}$ & $\begin{array}{l}\text { The frames are kept on a place where the } \\
\text { worker has to climb up the stairs and bring } \\
\text { it down }\end{array}$ & $\begin{array}{l}\text { The frames should be kept near the assembly } \\
\text { line only to cut down the redundant effort } \\
\text { and time }\end{array}$ \\
\hline $\begin{array}{l}\text { Differential } \\
\text { assembly }\end{array}$ & $\begin{array}{l}\text { The operator sits on stool and the work } \\
\text { table of assembly is on the floor. He has to } \\
\text { bend every time and do the assembly. }\end{array}$ & $\begin{array}{l}\text { A worktable must be installed at the arm } \\
\text { level to avoid this excessive fatigue. This } \\
\text { will not only reduce the time taken but also } \\
\text { increase his efficiency, and work quality. }\end{array}$ \\
\hline Assembly line & Only one line is used & $\begin{array}{l}\text { The other line should be brought in use. This } \\
\text { can considerably reduce the time taken. }\end{array}$ \\
\hline Floor plates & $\begin{array}{l}\text { The floor plates are kept quite far away } \\
\text { from the assembly line }\end{array}$ & $\begin{array}{l}\text { Stands can be made to keep the floor plates } \\
\text { at an arm's distance to the operator below the } \\
\text { assembly line only }\end{array}$ \\
\hline Bolts & $\begin{array}{l}\text { Assorted, and are kept in the same box. Due } \\
\text { to this a lot of time is wasted in searching } \\
\text { the required ones. }\end{array}$ & $\begin{array}{l}\text { The bolts should be segregated and kept is } \\
\text { separate containers for easy access }\end{array}$ \\
\hline Fixing the wheels & $\begin{array}{l}\text { Workers use random objects to ram the } \\
\text { wheels to the axle which increases the time } \\
\text { and undermines the quality }\end{array}$ & $\begin{array}{l}\text { A proper special purpose hammer should be } \\
\text { used for this task. }\end{array}$ \\
\hline Work division & $\begin{array}{l}\text { The division of labouris not proper } \\
\text { Tork needs to be properly distributed } \\
\text { amongst the workers so that they have } \\
\text { ownership and are accountable for their work }\end{array}$ \\
\hline
\end{tabular}

\section{A. Time calculation with proposed changes}

1. Stage 1

\begin{tabular}{|l|l|l|l|l|l|l|l|l|l|l|l|l|}
\hline $\begin{array}{l}\text { Element } \\
\text { No. }\end{array}$ & 1 & 2 & 3 & 4 & 5 & & & & & & &
\end{tabular}

Stage 1 observed times

\section{Stage 2}

\begin{tabular}{|c|c|c|c|c|c|c|c|c|c|c|c|}
\hline $\begin{array}{c}\text { Element } \\
\text { No. }\end{array}$ & 1 & 2 & 3 & 4 & 5 & 6 & 7 & 8 & 9 & 10 & 11 \\
\hline $\begin{array}{c}\text { Element } \\
\text { Type }\end{array}$ & $\mathrm{M}$ & $\mathrm{M}$ & $\mathrm{P}$ & $\mathrm{P}$ & $\mathrm{M}$ & $\mathrm{M}$ & $\mathrm{M}$ & $\mathrm{M}$ & $\mathrm{M}$ & $\mathrm{M}$ & $\mathrm{P}$ \\
\hline $\begin{array}{c}\text { Average } \\
\text { actual } \\
\text { time }\end{array}$ & .50 & .30 & 1 & 1 & .30 & 1 & 2.5 & 2 & 5 & 4 & .50 \\
\hline
\end{tabular}

Stage 2 observed times 
Selection of most time-consuming elements:

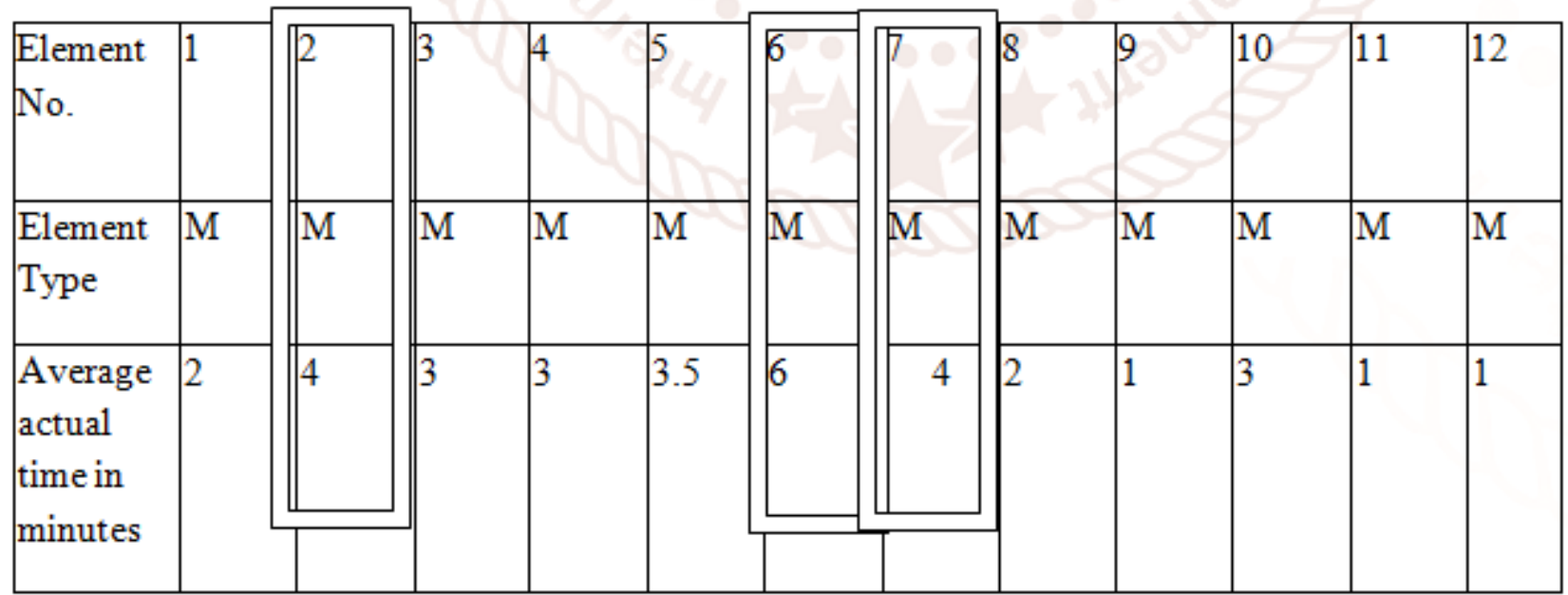

\section{Selection of most time-consuming elements:}

\begin{tabular}{|l|l|l|l|l|l|l|l|l|l|l|l|}
\hline $\begin{array}{l}\text { Element } \\
\text { No. }\end{array}$ & 1 & 2 & 3 & 4 & 5 & 6 & 7 & 8 & 9 & 10 & 11 \\
\hline $\begin{array}{l}\text { Element } \\
\text { Type }\end{array}$ & $\mathrm{M}$ & $\mathrm{M}$ & $\mathrm{P}$ & $\mathrm{P}$ & $\mathrm{M}$ & $\mathrm{M}$ & $\mathrm{M}$ & $\mathrm{M}$ & $\mathrm{M}$ & $\mathrm{M}$ & $\mathrm{P}$ \\
\hline $\begin{array}{l}\text { Average } \\
\text { actual } \\
\text { time in } \\
\text { minutes }\end{array}$ & .50 & .30 & 1 & 1 & .30 & 1 & 2.5 & 2 & 5 & 4 & .50 \\
\hline
\end{tabular}

Stage 2 new most time-consuming elements

Now, by using some PMT system, suppose we Rating factor for element $6=5.5 / 6=91.67 \%$. determine the times of these elements as

\begin{tabular}{|l|l|l|l|}
\hline Elements No. & 2 & 6 & 7 \\
\hline $\begin{array}{l}\text { Standard } \\
\text { operators time }\end{array}$ & 3.65 & 5.50 & 3.50 \\
\hline
\end{tabular}

Rating factor for element $2=3.65 / 4=91.25 \%$. Rating factor for element $7=3.50 / 4=87.5 \%$. The mean of the rating factors of selected elements $=$ $90.12 \%$ or say $90 \%$ is the rating factor that will be used for all the manual elements of the work cycle.

\section{a. Calculation of normal time:}

\section{Standard operator's time}

\begin{tabular}{|l|l|l|l|l|l|l|l|l|l|l|l|l|}
\hline Element No. & 1 & 2 & 3 & 4 & 5 & 6 & 7 & 8 & 9 & 10 & 11 & 12 \\
\hline Element Type & $\mathrm{M}$ & $\mathrm{M}$ & $\mathrm{M}$ & $\mathrm{M}$ & $\mathrm{M}$ & $\mathrm{M}$ & $\mathrm{M}$ & $\mathrm{M}$ & $\mathrm{M}$ & $\mathrm{M}$ & $\mathrm{M}$ & $\mathrm{M}$ \\
\hline $\begin{array}{l}\text { Average } \\
\text { actual time } \\
\text { (min) }\end{array}$ & 4 & 3 & 3 & 3 & 6 & 5 & 1 & 1 & 3 & 1 & 1 \\
\hline $\begin{array}{l}\text { Standard } \\
\text { operators } \\
\text { time (min) }\end{array}$ & & 3.6 & & & 2.7 & & & .9 & & & & \\
\hline
\end{tabular}


International Journal of Trend in Scientific Research and Development (IJTSRD) ISSN: 2456-6470

\begin{tabular}{|l|l|l|l|l|l|l|l|l|l|l|l|l|}
\hline $\begin{array}{l}\text { Performance } \\
\text { Rating Factor }\end{array}$ & 90 & 90 & 90 & 90 & 90 & 90 & 90 & 90 & 90 & 90 & 90 & 90 \\
\hline
\end{tabular}

\section{Normal time for Chassis assembly}

\begin{tabular}{|l|l|l|l|l|l|l|l|l|l|l|l|}
\hline Element No. & 1 & 2 & 3 & 4 & 5 & 6 & 7 & 8 & 9 & 10 & 11 \\
\hline $\begin{array}{l}\text { Element } \\
\text { Type }\end{array}$ & $\mathrm{M}$ & $\mathrm{M}$ & $\mathrm{P}$ & $\mathrm{P}$ & $\mathrm{M}$ & $\mathrm{M}$ & $\mathrm{M}$ & $\mathrm{M}$ & $\mathrm{M}$ & $\mathrm{M}$ & $\mathrm{P}$ \\
\hline $\begin{array}{l}\text { Average } \\
\text { actual time } \\
\text { (min) }\end{array}$ & .50 & 30 & 1 & 1 & .30 & 1 & 3 & 4 & 6 & 5 & .50 \\
\hline $\begin{array}{l}\text { Standard } \\
\text { operators } \\
\text { time (min) }\end{array}$ & & & & & & & & & & &
\end{tabular}

\section{Normal time for stage 2}

Normal time for Chassis $=0.90(2+4+3+3+3+6+5+1+1+3+1+1)$

\section{$=29.7 \mathrm{mins}$}

Normal time for stage 2= $.90(.50+.30+.30+1+3+3.6+5.4+4.5)+1(1+1+.50)$

$$
=16 \mathrm{mins}
$$

\section{b. Determining the standard time:}

The standard time is the sum of Normal time and allowances. Thus it is calculated as below:

Standard Time $=$ Normal Time + Allowances

$$
\begin{aligned}
& =29.7+1.5+1.93+2.7 \\
& =35.83 \mathrm{mins}
\end{aligned}
$$

\section{c. Percentage reduction in time}

The percentage reduction in time on application of our proposed changes

$$
\begin{aligned}
& =44.77-35.83 / 44.77 \\
& =19.97 \%
\end{aligned}
$$

\section{RESULTS AND DISCUSSION}

The present production of existing production line is 25 units/day. The working hours for this company are $8 \mathrm{hr}$. In this production line the total number of worker is 20 . So, the average productivity of this production line is approximately 1.25 units per day. In this production line, the available working time is 48000 minutes.

\section{CONCLUSION AND RECOMMENDATION}

Productivity improvement is an important issue in small-scale industry. The profit earning of this industry largely depends on productivity improvement. This study shows the way of finding gap of production process and operations. By implementing work study and method study and established new effective process for particular operation, we have to able to increase productivity. Especially this study shows the improvement of productivity in assembly area of E-rickshaw manufacturing industry.

The line balancing is the key point to increase productivity to particular products. For the sake of limitation, we could not apply this technique to all departments. For reducing work content to improve productivity, Lean manufacturing concept could be used for our work. This study shows the productivity improvement by reduction of work content and line balancing. Further research could be done by using combination of lean and work study technique.

In earlier the work content per piece was 44.77 minutes. After line balancing and critical analysis the 
work content was 35.83 minutes. So, that the work content reduced by 9 minutes after line balancing and critical method work.

Our proposed method helps to increase productivity to $19.97 \%$ with reduction of work content and line balancing.

\section{References}

[1] NPTEL Courses, IIT Roorkee, Industrial Engineering, Part 1 Lecture 9

[2] Shodhgana, Chapter 4 Stop Watch Time Study and MOST:Work Measurement Techniques

[3] Moktadir MA, Ahmed S, Fatema-Tuj-Zohra, Sultana R (2017) Productivity Improvement by Work Study Technique: A Case on Leather
Products Industry of Bangladesh. Ind Eng Manage 6:207doi:10.4172/2169-0316.1000207

[4] H A Salaam, Productivity improvement using industrial engineering tools, et al 2012 IOP Conf. Ser.: Mater. Sci. Eng. 36012006

[5] Syed Asad Ali Naqvi, Muhammad Fahad, Muhammad Atir, Muhammad Zubair, Muhammad Musharaf Shehzad \& Wenjun Xu (2016) Productivity improvement of a manufacturing facility using systematic layout planning, Cogent Engineering

[6] Hendy Tannady, Increasing the Efficiency and Productivity in the Production of Low VoltageSwitchboard Using Resource Constrained Project Scheduling, Journal of Industrial Engineering and Management,JIEM, 2018 11(1): 1-33 